\title{
Improving Technological Pedagogical Content Knowledge (TPACK) of Pre-Service English Language Teachers
}

\author{
Ceylan Yangin Ersanl1 ${ }^{1}$ \\ ${ }^{1}$ Department of Foreign Languages, Faculty of Education, Ondokuz Mayıs University, Samsun, Turkey \\ Correspondence: Ceylan Yangın Ersanlı, Faculty of Education, Ondokuz Mayıs University, Kurupelit-Atakum, \\ Samsun, Turkey. Tel: 90-36-2312-1919. E-mail: ceylanyangin@gmail.com
}

Received: January 29, 2016

Accepted: March 1, 2016 Online Published: April 13, 2016

doi:10.5539/ies.v9n5p18

URL: http://dx.doi.org/10.5539/ies.v9n5p18

\begin{abstract}
Developing as teachers and optimizing learning experiences for future students is the ultimate goal in technology use in teacher education programs. This study aims to explore the effectiveness of a five-week workshop and training sessions on Technological Pedagogical Content Knowledge (TPACK) of pre-service English language teachers. The participants are 59 pre-service English language teachers enrolled in an ELT Methodology Course at a state university. The data is gathered through the TPACK Scale developed by Solak and Çakır (2014) and journal entries of pre-service English language teachers before and after the procedure. The results indicate a statistically significant improvement in TPACK scores of both male and female pre-service English language teachers. The journal entries clearly indicate an increase in several possible applications or websites that can be used in the classroom with more effective and to the point objectives. The pre-service English language teachers have also displayed better performance in manufacturing and tailoring language learning/teaching materials with specific goals.
\end{abstract}

Keywords: pre-service English language teachers, Technological Pedagogical Content Knowledge (TPACK), technology integration

\section{Introduction}

Today children are growing up with technology. It is an indispensable part of their lives. However, it is a known fact that teachers' technology-related knowledge, skills and competencies fall short when compared with those of their technology-native students (Belland, 2009; Yalin, Karadeniz, \& Şahin, 2007; Lim \& Khine, 2006). This means that there is not only a lack in teachers' technology use but also in their integration of technology into their pedagogical applications.

Just the availability of more technology in schools today does not automatically guarantee better use and effectiveness. Teachers should be trained to make the best of educational technologies to support students' learning. This specific knowledge to optimize technology to support students' learning of the subject is termed technological pedagogical content knowledge (TPACK) (Mishra \& Koehler, 2006). Given the fact that several governments are investing in educational technologies, teacher education programs should equip their graduates accordingly. Technology can be used to improve student learning, support students and parents, make the school more engaging and relevant for the learners, provide equal opportunities for the disadvantaged students, allow for and support teacher professional development (Zuker, 2008).

Teaching and learning is defined as a complex activity that draws on many kinds of knowledge (Mishra \& Koehler, 2006, p. 1020). In the past, teaching and learning environment is defined as an intersection of two main domains; pedagogical and content knowledge (PCK). The idea was first proposed by Schulman (1986). PCK refers to the unique form of professional knowledge that teachers possess in making the content knowledge accessible to the students through some pedagogical methods (Chai, Koh, \& Tsai, 2013). Today, with the effects of educational technologies, Shulman's idea is built on by adding a new technology component. With the emergence of technological, pedagogical and content knowledge (TPACK) technology-supported courses have gained priority. In very broad terms TPACK can be defined as a framework which synthesizes digital technologies into classroom teaching and learning. The core components of TPACK are content knowledge (CK), pedagogical knowledge (PK), and the technological knowledge (TK). These three basic forms of knowledge have overlapping parts namely; pedagogical content knowledge (PCK), technological content knowledge (TCK), 
technological pedagogical knowledge (TPK) and the TPACK. The following figure illustrates the overlapping areas of knowledge.

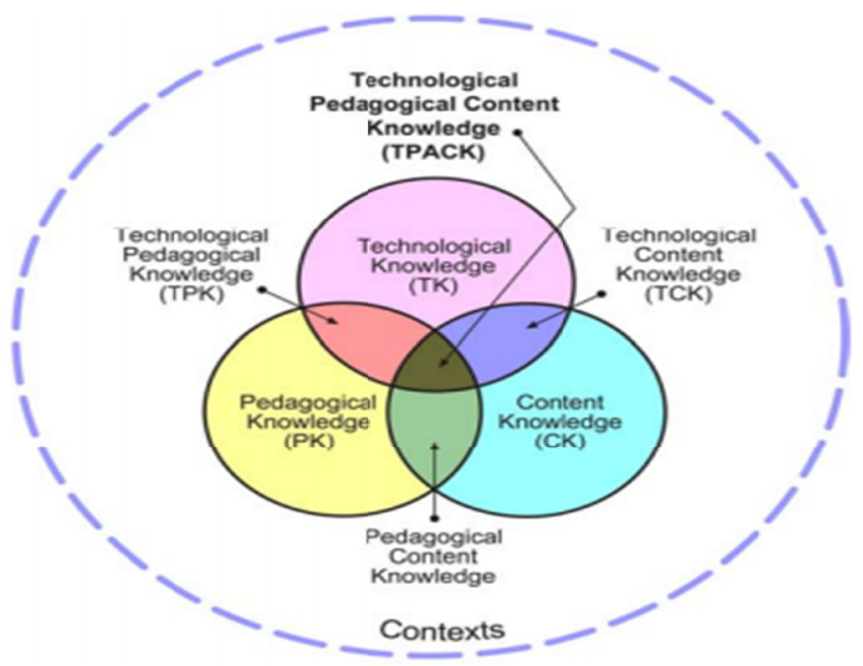

Figure 1. The components of the TPACK framework (graphic from TPCK - Technological Pedagogical Content Knowledge, 2010)

In these courses the aim is not to put technology in the center of teaching and learning. Teachers have to be not only technology-literate but also design teaching and learning activities that meaningfully integrate each of these domains (Koehler, Mishra, \& Yahya, 2007). TPACK is defined as "...the effective use of the technology within a teaching strategy as a pedagogical tool" (Cavin, 2007: 18). It involves the use of strategies that incorporate technology to enhance teaching and learning of content. In the instructional process teachers have to decide on the most appropriate technological tool to present a topic.

TPACK applications have been used in various disciplines. Especially, in the areas of science and mathematics there are several TPACK studies (Niess, 2005; Cavin \& Fernandez, 2007; Grandgenett, 2008; Leatham, 2008; Graham et al., 2009). However, the application of this framework to pre-service English language teacher education is a unique context (Abbitt, 2011: 283; Solak \& Çakır, 2014). Yet, in recent years many studies have been conducted on the applications of TPACK framework in the area of English language teaching profession. There are many reasons for this; in contexts where English is a foreign language, there is limited exposure to the target language outside the classroom. Digital technologies offer authentic English and as Liu et al. (2014) puts forward for EFL teachers how to use technological tools is a part of their professional knowledge of teaching.

The rapid developments in the area of digital technologies put the use of technology in the heart of nearly every aspect of individuals' lives. This broad use of technology has many positive effects on people's everyday lives. Education is not an exception. The teaching and learning environments are re-designed accordingly allowing to Internet access. Nearly all of the students have their personal computers. They are digital natives and can effectively use the Internet resources.

In the light of these technological developments it appears that there is a high expectancy for pre-service English language teachers' meaningful application of their technological knowledge into their profession. In this respect, it would be beneficial to be informed about TPACK applications in the area of English language teaching. Below is given some of these studies and their findings.

The study of Liu et al. (2014) focuses on the technological pedagogical content knowledge (TPACK) of English as a foreign language (EFL) teachers. The study concludes that the development of TPACK for EFL teachers is a connection of two sources of knowledge, i.e. the formal knowledge and skills provided and supported by schools and teaching community and the practical knowledge in using technology.

Abera's (2014) study addresses the existing literature on technological pedagogical content knowledge framework and of teacher education in Ethiopia in general and English language teacher education in particular. The results revealed that the existing literature failed to demonstrate the application of TPACK in English 
language teacher education in the country. The technological pedagogical content knowledge of classroom English language teachers was also found to be low in this study.

Öz (2015) tries to assess pre-service English as a foreign language teachers' technological pedagogical content knowledge. The findings revealed a highly developed knowledge of TPACK. Gender differences were found to be significant with respect to Technological Knowledge and Pedagogical Knowledge dimensions with females proportionally having higher TPACK development. In a similar study Solak and Çakır (2014) examined pre-service EFL teachers' TPACK competencies in Turkey in terms of gender and academic achievement. The results of the research suggest that males' technological knowledge was higher than females; however, females were better than males in pedagogical knowledge. Moreover, no significant difference was found between TPACK mean and academic achievement.

The study of Tai (2013) focuses on the effects of TPACK-in-Action workshops to English classrooms. The study used an observation instrument based on the TPACK framework (Mishra \& Koehler, 2006) to investigate the impact of TPACK-in-Action workshops had on English teachers in Taiwan. Findings showed that the TPACK-in-Action CALL workshops had a strong and positive impact on elementary English teachers in Taiwan.

Though many teachers do not ignore possible benefits of using digital resources to help students' academic achievement, several studies indicate teachers may be reluctant to use or integrate technology to support their classes (Conlon \& Simpson, 2003; Cuban, 2001; Watson, 2001). Among several reasons, not knowing how to effectively use technology can be cited as a major cause. Knowledge about technology is complex and dynamic. The ever-changing nature of technology requires constant up dating. Staying current might be time consuming for teachers. Yet, it is inevitable for teachers to acquire TPACK. To this end, a constructivist approach is thought to be effective in that knowledge is constructed through interactive experiences with the world and others. A perspective assuming experience as a necessary condition for the acquisition of knowledge might infer that training and workshop sessions help pre-service teachers acquire and improve TPACK.

To this end, the present study employed a five-week training and workshop on TPACK for pre-service English language teachers in a state university as a part of their course requirement. The following research questions guided the study:

1) Will TPACK of pre-service English language teachers improve as a result of TPACK training and workshops?

2) Do TPACK of pre-service English language teachers differ according to gender?

3) What are the opinions of pre-service English language teachers about TPACK training and workshops?

\section{Method}

\subsection{Research Design}

The study employed a mixed design involving both qualitative and quantitative research methods. Quantitative data was gathered through TPACK Scale developed and validated by Solak and Çakır (2014). The pre-service English language teachers also kept journals prior to and after the training and workshops. Content analysis of the journals provided qualitative data.

\subsection{Participants and Setting}

The participants of the study were 59 pre-service teachers in an English Language Teacher Training Program in a state university. The participants were on their third year of training. That was the year when methodology courses (the courses about pedagogy and language teaching) were the most. Other information about the participants is below:

Table 1. Demographics of the participants

\begin{tabular}{cccccccc}
\hline \multicolumn{2}{c}{ Gender } & \multicolumn{2}{c}{ Daily time spent on the Internet } & \multicolumn{2}{c}{ Personal Computer } & \multicolumn{2}{c}{ Social Media } \\
\hline F & 40 & Up to 1 hour & 8 & Yes & 54 & Yes & 56 \\
M & 19 & $1-3$ hours & 30 & No & 5 & No & 3 \\
& & $4-7$ hours & 14 & & & & \\
& & More than 8 hours & 7 & & & & \\
\hline
\end{tabular}


The gender ratio was common in teacher training programs in Turkey. It appears the average participants in the study were pre-service English language teachers possessing a personal computer, using social media and spending between 1-7 hours on the net. That none of the participants was a computer novice was important because it might be assumed that already acquired familiarity with digital technologies and computer literacy eliminated the barriers resulting from lack of computer skills.

\subsection{Data Collection and Analysis}

The pre-service English language teachers took the TPACK inventory before and after the TPACK training and workshops. The TPACK scale was developed by Solak and Çakır (2014). The data was analyzed using SPSS 21 program. The Kolmogorov-Smirnov test revealed normal distribution (.200) and paired samples t-test results and descriptive statistics findings were presented.

The participants were also asked to keep journal entries before and after the TPACK training and workshops. The pre-service English language teachers were asked to write about how ICT skills, their pedagogical knowledge and ELT knowledge could be integrated to teach English. They were also asked to describe actual educational technology activities to teach English effectively both before and after the training and workshops. The journal entries were analyzed through Constant Comparison Method suggested by Miles and Huberman (1994), which yields themes and patterns as a result of sorting, coding and connecting pieces of data. Two raters sorted, coded and identified the categories separately to ensure reliability of qualitative analysis. The inter-rater reliability the formula (the number of agreements/the number of agreements (x) the number of disagreements multiplied by 100) suggested by Tawney and Gast (1984) was used. The inter-rater reliability of the qualitative data in the study was found .90 , which indicated a high consensus on the coding and categorisation of data (Gwet, 2014).

\section{Findings and Discussion}

\subsection{Analysis of the TPACK Scale}

Table 2. T-test results of total TPACK scores before and after the training and workshops

\begin{tabular}{lccccccc}
\hline & Mean & $\mathrm{N}$ & Std. Dev. & Std. Error Mean & $\mathrm{t}$ & $\mathrm{df}$ & Sig. (2-tailed) \\
\hline Pre-TOTAL & 75.729 & 59 & 12.2978 & 1.6010 & -2.303 & 58 & $.025^{*}$ \\
Post-TOTAL & 78.881 & 59 & 12.0689 & 1.5712 & & & \\
\hline
\end{tabular}

$* \mathrm{p}<0.05$.

The paired samples $t$ test results indicated a 0.025 significance between pre and post test results. The total means showed that the pre-service English language teachers improved their total scores in the post-test. It can be concluded that the TPACK training and workshops served the purpose.

A more detailed analysis revealed comparison of the subcategories of the scale in terms of participants means scores in pre- and post- applications of the scale. The findings are below: 
Table 3. Sub-categories of TPACK scores

\begin{tabular}{cccccccc}
\hline \multicolumn{7}{c}{ Paired Samples Statistics } \\
\hline \multirow{2}{*}{ TK } & Mean & Std. Dev. & $\begin{array}{c}\text { Std. Error } \\
\text { Mean }\end{array}$ & $\mathrm{t}$ & $\mathrm{df}$ & Sig. (2-tailed) \\
& Pre & 8.44 & 2.775 & .361 & -.407 & 58 & .686 \\
CK & Post & 8.53 & 2.781 & .362 & & & \\
& Pre & 9.19 & 1.686 & .220 & -1.690 & 58 & $.096^{*}$ \\
& Post & 9.59 & 1.693 & .220 & & & \\
PK & Pre & 6.27 & 1.298 & .169 & -3.194 & 58 & $.002^{*}$ \\
& Post & 6.81 & 1.332 & .173 & & & $.013^{*}$ \\
PCK & Pre & 15.24 & 2.926 & .381 & -2.576 & 58 & .954 \\
& Post & 16.32 & 2.616 & .341 & & & \\
TPK & Pre & 10.59 & 2.167 & .282 & .058 & 58 & .075 \\
& Post & 10.58 & 2.151 & .280 & & & .231 \\
TCK & Pre & 13.00 & 2.754 & .359 & -1.814 & 58 & \\
& Post & 13.64 & 2.354 & .307 & & & \\
TPCK & Pre & 13.00 & 2.546 & .331 & -1.211 & 58 & \\
& Post & 13.41 & 2.647 & .345 & & & \\
\hline
\end{tabular}

TK-Technological Knowledge, CK-Content Knowledge, PK-Pedagogical Knowledge,

PCK-Pedagogical Content Knowledge, TPK-Technological Pedagogical Knowledge,

TCK-Technological Content Knowledge, TPCK-TechnologicalPedagogical Content Knowledge.

As for sub-categories of the scale, the pre-service English language teachers' performance indicated statistically significant difference in Content Knowledge, Pedagogical Knowledge and Pedagogical Content Knowledge. The mean scores for each section revealed an improvement in post-scores. It may be concluded that the trainings and workshops improved content and pedagogical knowledge of the pre-service English language teachers.

In order to investigate the gender factor, male and female pre-service English language teachers' total scores on the TPACK scale were compared below:

Table 4. Comparison of TPACK scores according to gender

\begin{tabular}{lcccccccc}
\hline & Gender & $\mathrm{N}$ & Mean & Std. Dev. & $\begin{array}{c}\text { Std. Error } \\
\text { Mean }\end{array}$ & $\mathrm{t}$ & $\mathrm{df}$ & Sig. (2-tailed) \\
\hline Pre-TOTAL & $\mathrm{M}$ & 19 & 84.842 & 11.1717 & 2.5630 & 4.537 & 57 & $.000^{*}$ \\
& $\mathrm{~F}$ & 40 & 71.400 & 10.3745 & 1.6404 & 4.417 & 33.196 & $.000^{*}$ \\
Post-TOTAL & $\mathrm{M}$ & 19 & 85.263 & 12.4090 & 2.8468 & 2.984 & 57 & $.004^{*}$ \\
& $\mathrm{~F}$ & 40 & 75.850 & 10.7835 & 1.7050 & 2.837 & 31.367 & $.008^{*}$ \\
\hline
\end{tabular}

$* \mathrm{p}<0.05$.

The scores of male and female pre-service English language teachers presented statistically significant difference in pre- and post- applications of the TPACK Scale. Both groups increased their mean scores, however, the increase in female pre-service English language teachers was a lot higher though they were poorer at the beginning.

\subsection{Analysis of the Journal Entries}

The qualitative analysis of the journals before the TPACK training yielded the results below: 
Table 5. Journal entries before the TPACK training and workshops

\begin{tabular}{ll}
\hline Software and applications & Purpose \\
\hline The Internet & increase in motivation \\
Facebook & fun in learning \\
Twitter & interesting lessons \\
Skype & group work \\
Youtube & homework \\
e-mail & catering for multiple intelligences and different learning styles \\
Chat & contact with people abroad \\
Blogs & improving listening \\
Online dictionaires & improving pronunciation \\
Powerpoint & developing vocabulary \\
Some useful websites & grammar worksheets \\
Authentic materials & time saving \\
Penpalls & \\
Videos & \\
Movies & \\
Visuals & \\
Games & \\
Animations & \\
Materials and worksheets & \\
Smart phones & \\
Interactive boards & \\
Recorders & \\
Tablets & \\
\hline
\end{tabular}

Before the TPACK training and workshops the pre-service English language teachers listed several applications, websites and hardware as new technology to be used in the classroom. They emphasized the potential that new technologies might foster motivation and interest into the lessons. They stated that these applications could spice up their classroom. Most of those cited were well-known applications and websites such as Facebook, Twitter, Skype and Youtube. However, as for the purpose, they could only mention very limited and superficial uses such as improving listening, pronunciation and vocabulary. They failed to explain how learning objectives could be achieved. An extract from a pre-service English language teacher says: "I know technology is a part of our lives in this era. The smart boards, smart phones, computers and etc. are in our lives. I know I should use them in education too. But how? I don 't have sufficient knowledge and skills about it'. Similarly, although the pre-service English language teachers were aware of the individual differences of students such as multiple intelligences and learning styles, they could not provide the procedures about how to cater for different students integrating technology, content knowledge and appropriate pedagogy.

A similar qualitative analysis was carried out after the TPACK training and workshops and the findings are below: 
Table 6. Journal entries after the TPACK training and workshops

\begin{tabular}{|c|c|}
\hline Software and applications & Purpose \\
\hline The Internet & Motivation for digital natives \\
\hline Edmodo & Enriched classrooms \\
\hline Facebook groups & Fun in learning \\
\hline Skype & Indirect and natural learning through rich input \\
\hline chatting & Warm-up and Brainstorming \\
\hline Youtube & Creating posters in the Padlet \\
\hline Blogs & Word clouds with Wordle \\
\hline Wordle & Creating posters with video, text and visuals through Glogster \\
\hline Padlet & Listening \\
\hline Webquests & Podcasts at all levels \\
\hline Podcasts & Using movies, TV and radio broadcasts and songs \\
\hline Voki & Pronunciation \\
\hline Glogster & Improving pronunciation through online dictionaries \\
\hline Penzu & Improving pronunciation using text-to-speech websites \\
\hline Digital storytelling & Speaking \\
\hline (Storybird/Goanimate/Storymaker) & Real communication and interaction with native speakers \\
\hline Powerpoint & Brainstorming and speaking through websites such as the \\
\hline Prezi & Dictionary of Obscure Sorrows \\
\hline Pintrest & Vocabulary \\
\hline Hotpotatoes & Learning and retention of vocabulary through Wordle, puzzles, \\
\hline Interpals (penpalls website) & games, Pixton \\
\hline Postcrossing & Reading \\
\hline Claroline & e-books \\
\hline e-twinning project & novels and stories with audio \\
\hline e-portfolios & newspapers and magazines as authentic materials \\
\hline Pixton & Writing \\
\hline Telegami & Authentic communication with people abroad through interpal/ \\
\hline eslgames.com & postcrossig etc. \\
\hline brainpop.com & Publishing and sharing in blogs \\
\hline The Dictionary of Obscure Sorrows & Keeping an online diary and sharing it with the teacher \\
\hline British Council & Online writing centers for academic writing \\
\hline $\mathrm{BBC}$ & Grammar \\
\hline Online writing centers & Extending mechanical drills and restricted activities outside the \\
\hline Online stories & class through eslworksheets, printables, quizes and clozetests using \\
\hline Newspapers & hotpotatoes \\
\hline ESL websites & Grammar can be integrated with other skills \\
\hline Moviemaker & Integrated Skills \\
\hline Authentic materials & Webquests and internet based research tasks \\
\hline Online dictionaries (tureng/ zargan & Digital story websites to create students' own stories \\
\hline etc) & Cross-curricular tasks \\
\hline Visuals & Improving collaboration and critical thinking \\
\hline
\end{tabular}




Movies
Broadcasts
Smart phones
FATIH Project (interactive boards
and tablets)
Projectors

\section{Culture}

Fill the gap in intercultural background knowledge

\section{Social Networks}

Using Edmodo to contact the teacher and classmates, to share documents, give feedback and assign homework

Using Claroline to share materials, slides, worksheets and homework

Help students meet foreign friend with e-twinning

\section{Audio Visual Materials}

Attractive presentations through Prezi and Powerpoint

\section{Individual Differences}

Self-paced learning opportunities

Learner autonomy

Catering for learners with different intelligences and learning styles Various material for different levels, different interests and different developmental stages

\section{Materials Development}

Teachers can create their own animations and stories through

Telegami, Goanimate, Storybird

Teachers can tailor the coursebook for their students' needs

After the TPACK training and workshops, the journal entries of pre-service English language teachers revealed a much larger list of online applications, software and websites. Most of these applications and websites were related to educational purposes. The possible purposes to use technology had increased a great deal. Moreover, the pre-service English language teachers' awareness about how to optimize learning conditions had expanded. They could clearly specify how these new technologies could be used in the classroom to increase motivation and to achieve intended learning outcomes. The journals revealed descriptions of several actual classroom procedures and materials developed by the pre-service English language teachers. One example described by one of the pre-service English language teachers is "we created an animated conversation between four kids using Goanimate. They were from different cultures: British, Indian, Chinese and African. Then we used Glogster to prepare posters about their cultures and gathered a lot of information. Finally we used Wordle to teach some vocabulary". As a result of the materials development workshops, the pre-service English language teachers gained knowledge and skills in integrating technology with their content knowledge and pedagogical knowledge effectively. The time, thought and effort spent appeared to pay as the pre-service English language teachers could describe much more specifically what could be done. They listed a wide range of possible uses of technology to achieve learning outcomes in the classroom. These included the skills, grammar, vocabulary and pronunciation as well as cultural and motivational aspects, cross-curricular tasks, classroom management, student-centeredness and materials development. The pre-service English language teachers pointed that it was the pedagogical knowledge that helped them understand and determine the needs of students and the content knowledge along with it to prepare learning environments and materials accordingly to meet the desired learning outcomes.

\section{Conclusion}

Being able to teach with technology requires an understanding of how technology, pedagogy and content interact to support student learning; to be precise, it involves the skill and knowledge to make use of a digital tool or application with its all features, limitations and possibilities, to support students' learning of a given topic or content. To this end, this study aimed to investigate the effect of the TPACK workshops and training on pre-service teachers.

Both qualitative and quantitative data gathering methods were used in the study. The data gathered from the TPACK scale used before and after the training suggested a statistically significant increase in the pre-service English language teachers' level of TPACK. This result was in parallel with the findings of other studies (Tai, 
2013; Kurt, Mishra, \& Koçoğlu, 2013). When we look at the sub-categories of TPACK scale, we see that not only the overall TPACK levels of the pre-service English language teachers revealed an improvement but also the training and the workshops had a positive effect on the subcategories of TPACK such as content knowledge, pedagogical knowledge and pedagogical content knowledge. This finding has vital importance since being able to teach effectively with technology requires an understanding of how technology, pedagogy and content interact with each other meaningfully.

As for the second research question, although both of the groups revealed an increase in their mean scores in the post test. The statistical results suggested a higher increase in female pre-service English language teachers' post test results when compared with the males. Studies (Öz, 2015; Solak \& Çakır, 2014) revealed a significant difference in favor of males in terms of technological knowledge. On the other hand, females in these studies scored higher than males in pedagogical knowledges. Similarly, in this study the males when we look at the results of the pre-test scored higher than the females in technological knowledge. However, although both of the groups revealed a statistically significant increase in their TPACK levels, female pre-service English language teachers revealed a much higher improvement in their technological knowledge after the training.

The study suggested that training and workshop studies were effective in improving pre-service English language teachers' awareness of possible and effective uses of digital technologies in the classroom for educational purposes. The pre-service English language teachers could gain knowledge and skills in integrating technology with their content knowledge and pedagogical knowledge by producing actual learning materials. Therefore, it is suggested that TPACK training and materials development workshops should be integrated into teacher training programs.

\section{References}

Abbitt, J. T. (2011). Measuring Technological Pedagogical Content Knowledge in Preservice Teacher Education: A Review of Current Methods and Instrument. Journal of Research on Technology in Education, 43(4), 281-300. http://dx.doi.org/10.1080/15391523.2011.10782573

Abera, B. (2014). Applying a Technological Pedagogical Content Knowledge Framework in Ethiopian English Language Teacher Education. In T. Issa, P. Isaías, \& P. Kommers (Eds.), Multicultural Awareness and Technology in Higher Education: Global Perspectives. IGI Global. http://dx.doi.org/10.4018/978-1-4666-5876-9.ch014

Belland, B. R. (2009). Using the theory of habitus to move beyond the study of barriers to technology integration. Computers \& Education, 52(2), 353-364. http://dx.doi.org/10.1016/j.compedu.2008.09.004

Cavin R., \& Fernandez, M. L. (2007). Developing technological pedagogical content knowledge in preservice math and science teachers. In C. Crawford et al. (Eds.), Proceedings of Society for Information Technology and Teacher Education International Conference 2007. Chesapeake, VA: AACE.

Cavin, R. M. (2007). Developing Technological Pedagogical Content Knowledge in Preservice Teachers through Microteaching Lesson Study. Electronic Theses, Treatises and Dissertations, Paper 4017.

Chai, C.-S., Koh, J. H.-L., \& Tsai, C.-C. (2013). A Review of Technological Pedagogical Content Knowledge. Educational Technology \& Society, 16(2), 31-51.

Conlon, T., \& Simpson, M. (2003). Silicon Valley versus Silicon Glen: The impact of computers upon teaching and learning: A comparative study. British Journal of Education Technology, 34(2), 137-150. http://dx.doi.org/10.1111/1467-8535.00316

Cuban, L. (2001). Oversold and underused - computers in the classroom. Cambridge: Harvard University Press.

Graham, C. R., Burgoyne, N., Cantrell, P., Smith, L., St. Clair, L., \& Harris, R. (2009). TPACK development in science teaching: Measuring the TPACK confidence of inservice science teachers. TechTrends, 53(5), 70-79. http://dx.doi.org/10.1007/s11528-009-0328-0

Grandgenett, N. F. (2008). Perhaps a matter of imagination: TPCK in mathematics education. In AACTE Committee on Innovation and Technology (Ed.), The Handbook of Technological Pedagogical Content Knowledge (TPCK) for Educators. New York: American Association of Colleges of Teacher Education and Routledge.

Gwet, K. L. (2014). Handbook of Inter-rater Reliability: The Definitive Guide to Measuring the Extent of Agreement among Raters. Gaithersburg MD: Advanced Analytics.

Koehler, M., Mishra, P., \& Yahya, K. (2007). Tracing the development of teacher knowledge in a design seminar: 
Integrating content, pedagogy, and technology. Computers and Education, 49(3), 740-762. http://dx.doi.org/10.1016/j.compedu.2005.11.012

Kurt, G., Mishra, P., \& Kocoglu, Z. (2013, March). Technological pedagogical content knowledge development of Turkish pre-service teachers of English. Paper presented at the meeting of the Society for Information Technology and Teacher Education, New Orleans, LA. Retrieved from http://academicexperts.org/conf/site/2013/papers/38476/

Leatham, K. (2008). The development of technological pedagogical content knowledge in "Technology, Pedagogy and Mathematics" courses in the U.S. In C. Crawford et al. (Eds.), Proceedings of Society for Information Technology and Teacher Education International Conference 2007. Chesapeake, VA: AACE.

Lim, C. P., \& Khine, M. (2006). Managing teachers' barriers to ICT integration in Singapore schools. Journal of Technology and Teacher Education, 14(1), 97-125.

Liu, S., Liu, H., Yu, Y., Li, Y., \& Wen, T. (2014). TPACK: A New Dimension to EFL Teachers' PCK. Journal of Education and Human Development, 3(2), 681-693.

Miles, M. B., \& Huberman, A. M. (1994). Qualitative Data Analysis (2nd ed.). Thousand Oaks, CA: Sage Publications.

Mishra, P., \& Koehler, M. (2006). Technological Pedagogical Content Knowledge: A framework for teacher $\begin{array}{lllll}\text { knowledge. Teachers } \quad \text { College 108(6), Record, } & \text { 1017-1054. }\end{array}$ http://dx.doi.org/10.1111/j.1467-9620.2006.00684.x

Niess, M. L. (2005). Preparing teachers to teach science and mathematics with technology: Developing a technology pedagogical content knowledge. Teaching and Teacher Education, 21(5), 509-523. http://dx.doi.org/10.1016/j.tate.2005.03.006

Öz, H. (2015). Assessing Pre-service English as a Foreign Language Teachers' Technological Pedagogical $\begin{array}{lllll}\text { Content Knowledge. International Education } & \text { Studies, } & \text { 8(5), } & \text { 119-130. }\end{array}$ http://dx.doi.org/10.5539/ies.v8n5p119

Shulman, L. S. (1986). Those who understand: Knowledge growth in teaching. Educational Researcher, 15(2), 4-14. http://dx.doi.org/10.3102/0013189X015002004

Solak, E., \& Çakır, R. (2014). Examining Preservice EFL Teachers' TPACK Competencies in Turkey. The Journal of Educators Online, 11(2), 1-22.

Tai, S. D. (2013). From TPACK-in-Action Workshops to English Classrooms: CALL Competencies Developed and Adopted into Classroom Teaching. Graduate Theses and Dissertations. Paper 13335.

Tawney, J. W., \& Gast, D. L. (1984). Single Subject Research in Special Education. Columbus, OH: Charles E. Merrill Co.

Technological Pedagogical Content Knowledge (TPCK). (2010). Retrieved December 18, 2015, from http://tpack.org

Watson. D. (2001). Pedagogy before Technology: Re-thinking the relationship between ICT and teaching. Education and Information Technologies, 6(4), 251-266.

Yalın, H. I., Karadeniz, S., \& Şahin, S. (2007). Barriers to information and communication technologies integration into elementary schools in Turkey. Journal of Applied Sciences, 7(24), 4036-4039.

\section{Copyrights}

Copyright for this article is retained by the author(s), with first publication rights granted to the journal.

This is an open-access article distributed under the terms and conditions of the Creative Commons Attribution license (http://creativecommons.org/licenses/by/3.0/). 